\title{
Life cycle assessment: Study linkage between environment supply chain management and sustainability of supply chain
}

\author{
Ahmad Hidayat Sutawidjaya ${ }^{a^{*}}$, Lenny Christina Nawangsari ${ }^{a}$ and Norashidah Mohamed Nor ${ }^{b}$
}

${ }^{a}$ University of Mercu Buana, Jakarta, Indonesia

${ }^{b}$ University Malaysia Terengganu, Malaysia

\section{H R O N I C L E}

Article history:

Received August 15, 2020

Received in revised format

September 8, 2020

Accepted October 92020

Available online

October 92020

Keywords:

Life Cycle Assessment (LCA)

Environment Supply Chain

Management (ESCM)

Sustainability Supply Chain

\section{A B S T R A C T}

The most significant impacts on the environment and society of corporate operations occur in the supply chain. Environmental impacts occur at different stages of the environmental life cycle and relate to the extraction of raw materials from the earth, the processing and manufacturing of building materials, the construction process, operation or use, maintenance and repair, repair and eventual disposal or reuse of materials. Environmental phenomena of climate change or global warming are the result of human practice. Global warming causes an increase in ocean temperatures and surface of the book, causing melting of polar ice caps and rising sea levels. Another phenomenon of waste and sewage problems has become a national and international problem. Every supply chain activity in a series of production activities has an impact on the environment. Supply chains can have different organizational structures that reflect business relationships or the level of collaboration between chain companies. This study examines the relationship of Life Cycle Assessment (LCA) with Environment Supply Chain Management (ESCM) and Sustainability Supply Chain in Manufacture in Indonesia.

(C) 2021 by the authors; license Growing Science, Canada

\section{Introduction}

At present, there has been an increase in the need for industrial countries to address the problem of sustainable development. The philosophy of "sustainable development" has gained increasing interest from various public institutions, consumers, and companies to consolidate their position in a market that is always harmonized with environmental problems. Environmental problems play an increasingly important role in the decision-making process at all levels, namely: politics, economics, industry, and individuals. Not just a trend, increased attention to environmental problems comes from basic observations: because of their limited capacity to absorb the effects of human activities, the environment sets limits for the development of society. The current environmental phenomenon is climate change. Climate change or global warming is the result of human practices such as greenhouse gas emissions. Global warming causes an increase in ocean temperatures and surface of the book, causing the melting of polar ice caps and rising sea levels. It also changes the natural pattern of the season and rainfall such as flash floods, excessive snow. As a result of these weather changes, agricultural production often experiences crop failure and increases the chances of forest fires due to a prolonged dry season. Another phenomenon of waste and sewage problems has become a national and international problem. Solid waste problems are closely related to population growth, economic growth, and changes in community consumption patterns. In 2017, Indonesia's population has reached 261.89 million, an increase compared to 2000 which amounted to 206.26 million. The trend of economic growth also continues to increase, with the largest contribution from the manufacturing sector. Gross Domestic Product (GDP) produced from this sector amounted to 2,739.4 trillions in 2017, an increase from 2000 which was only 385.5 trillion.

* Corresponding author

E-mail address: a.h.sutawijaya@mercubuana.ac.id (A. H. Sutawidjaya)

(C) 2021 by the authors; licensee Growing Science. doi: $10.5267 /$ j.uscm.2020.10.003 
Rapid growth in the industrial sector is also the impact of increased household incomes and increasingly diverse patterns and types of public consumption. These conditions cause an increase in volume, variety of types, and characteristics of waste and waste. According to KLHK and the Ministry of Industry in 2016, the amount of waste generation in Indonesia has reached 65.2 million tons per year. Waste generation and waste disposal have a negative impact on the environment and health; therefore, it is necessary to take steps to deal with it (Central Bureau of Statistics, 2018). The concept of sustainability is always discussed in the headlines, but it is far more difficult to take action. For a sustainable future, statements, and studies that will be followed by meaningful actions that effectively reduce environmental impacts, and can even improve the situation. For effective action, three conditions must be met namely first, technological solutions must be available. Second, various solutions are prioritized and best practices are chosen, taking into account environmental efficiency, costs, and those that result in economic constraints. Finally, concrete steps must be optimized to reduce the impact that is far more on the environment. Every supply chain activity in a series of production activities has an impact on the environment. The supply chain consists of all parts of the company and related trading partners. Supply chains can have different organizational structures that reflect business relationships or the level of collaboration between chain companies. This structure ranges from informal, where companies occasionally make purchases from diverse groups of suppliers, joint ventures, or integrated supply chains where there is a high level of cooperation and dependence. Life Cycle Assessment (LCA) is one approach that can be used to identify and analyze environmental impacts. LCA is a method based on the analysis of the whole cycle, from the beginning of the process until the final manufacture that can be used to determine the amount of energy, costs, and the impact of liabilities that arise in each cycle of a product from the moment of the collection of raw materials to the end of the product life, including waste treatment. This study examines the relationship of Life Cycle Assessment (LCA) with Environment Supply Chain Management (ESCM) and Sustainability Supply Chain in Manufacture Indonesia

\section{Literature Review}

\subsection{Life Cycle Assessment (LCA)}

Life cycle assessment (LCA) can be seen as the main instrument of ESCM; it is a technique for gathering data on environmental care issues, which can be used to restructure supply chains in order to improve the environmental performance of those supply chains. The Life cycle assessment (LCA) method functions to analyze the potential environmental impacts arising from an activity, by knowing the inputs used, both energy and natural resources. This method can also be used to maximize output with the same input, reduce the use of raw materials and transportation, implement pollution control, reduce emissions in the environment, and utilize waste (Chauhan et al., 2011). LCA is one of the techniques developed to reduce the environmental impact caused by an industry (production and consumption), so that in the end it is able to provide protection to the environment (Finkbeiner, 2013). LCA can be done with a life cycle approach and can be used for carbon accounting and to evaluate other important environmental impacts such as acidification, ozone depletion, eutrophication, smoke, and health effects on humans (Aziz et al., 2016).

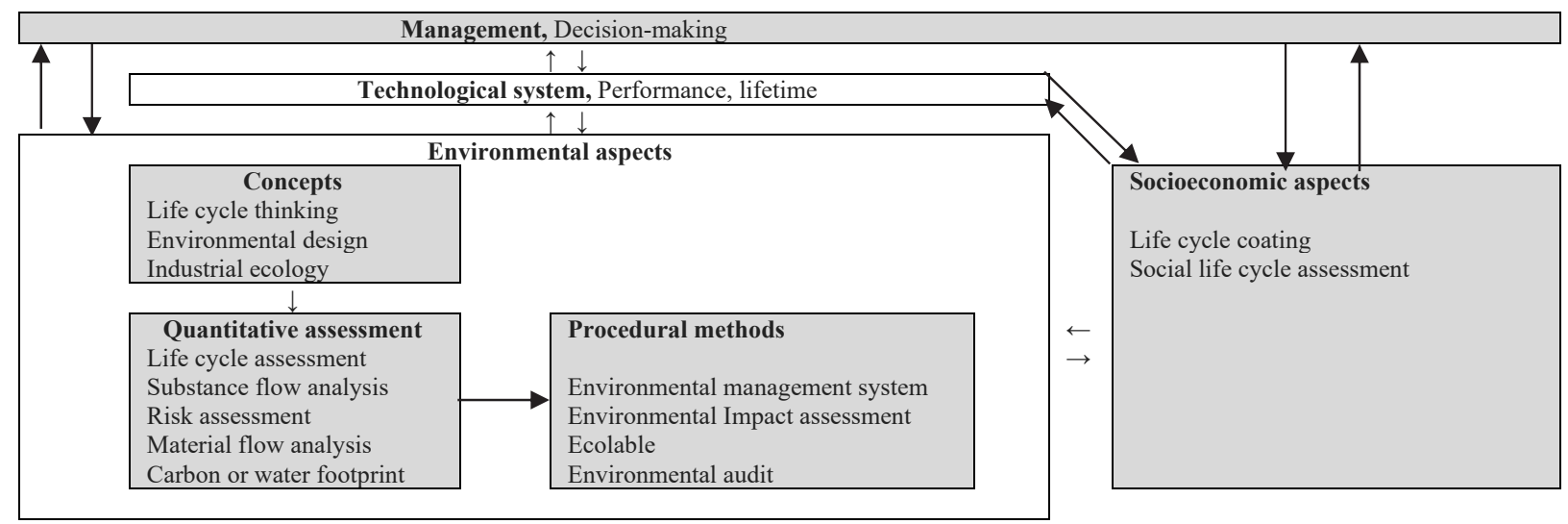

Fig. 1. General Principles of Life Cycle Assessment, Relationships between various tools to assess the sustainability of a good or service (Wrisberg et al., 2002).

Fig. 1. illustrates the positioning of LCA in relation to other environmental instruments and other more general approaches to sustainable development. In general, actions and policies are directly influenced by overarching concepts and procedural environmental method. These procedural methods are often based on environmental quantitative assess- ment tools, the most commonly used of which are described as follows (Wrisberg et al., 2002):

- A life cycle assessment quantifies a large number of resources uses, substance flows, and environmental accumulations to estimate multiple environmental impacts associated with a given function.

- A substance flow analysis (SFA) quantifies the flows and environmental accumulation of either a single substance, such as mercury, or a group of substances, such as inorganic nitrate compounds. 
- A risk assessment (RA) studies the risk or the probability of severe impacts occurring from an installation (such as a nuclear power plant) or the risks of using a chemical substance.

- A material flow analysis (MFA) tracks the flow of material in the economy of a given region. This is usually a raw material, such as paper, glass, concrete, or plastics.

- A carbon footprint (CF) determines the direct and indirect emissions of greenhouse gases due to a product, a human activity, or a business.

- A water footprint (WF) determines the impacts associated with water as an area of concern, including water usage and environmental exposures related to water quality.

\subsection{Defining Supply Chain Scope}

The concept of Supply Chain Management was born and brought a new facet to company management in the 1980s (AlfallaLuque et al., 2013). SCM has gained a strategic relevance as a source of competitive advantage and managing value on supply chains has becoming critical for company survival and growth.

Mentzer et al. (2001) defined a supply chain as a set of three or more entities (organizations or individual) directly involved in the upstream flows of products, services, finances, and/or information from a source to a customer.

\subsection{Defining Supply Chain Management}

Supply chain includes all activities associated with the flow and transportation of goods, from raw materials (inbound logistics) to finished products (outbound logistics) and also information flow. Supply chain management (supply-chain management) is the integration of activities in the procurement of materials and services, conversion into semi-finished goods and final products, and delivery to customers. The aim is to build a supplier chain that focuses on maximizing value for customers. The key to effective supply chain management is to make suppliers a partner in the company's strategy to meet an ever-changing market (Heizer, 2016).Supply Chain Management (SCM) is a physical network consisting of a series of company companies involved in providing raw materials, producing goods, or sending them to customers or end users. By managing information flow, product flow, and material flow between suppliers and distributors using Supply Chain Management (Sutawidjaya \& Nawangsari, 2017; Nawangsari \& Sutawijaya, 2019).

\subsection{Sustainable supply chain management}

Sustainable Supply Chain Management (SSCM) is an important strategy that supports organizations in achieving advantages over their competitors and in improving the overall performance. Wagner et al. (2001) believe that SSCM strategies' effects are still unclear and may cause positive or negative economic performance. Therefore, the advantages and barriers for SSCM have been discussed in this research to clarify some of this ambiguity. The goals of an SSCM are to provide a maximum value to all stakeholders and to fulfill customer requirements by achieving sustainable flows of products, services, information, and capital as well as enabling the cooperation among SC participants.

\subsection{The Importance Sustainable supply chain management}

Integrating environmental practice in SCM activities will help organizations achieve many advantages. Many researchers explore the advantages of the SSCM and believe that applying SSCM will help in reducing environmental risks, pollution, and improving environmental performance (Crum et al., 2011; Carter \& Rogers, 2008; Liang \& Chang, 2008). They assert that by applying SSCM, organizations will achieve marketing advantages, improve corporate image and organizational reputation. Cost reduction is another important advantage for implementing SSCM. In addition, Farahani et al. (2009) believe that it is important to integrate suppliers in a participative decision-making process, and protecting brand reputation and addressing corporate social responsibility. Crum et al. (2011) summarize the benefits of using SSCM by reducing packaging through using more effective design for reuse and recycling, lowering health and safety costs, reducing turnover and workforce costs due to safer warehousing and transport, improving product quality, and lowering disposal costs. Certain environmental and social initiatives help organization in having the closest relationship to consumers by sponsoring environmental activities and providing grants for local environmental projects and activities.

\subsection{Environmental Supply Chain Management}

Environment Supply Chain Management recognizes the crucial role played by the purchase and participation based on activities that include reduction, recycling, reuse and material substitution. Work with suppliers on environmental not only significant environmental benefits issues, but also cost control opportunities, improved risk management and better quality and branding. This will also help companies streamline their supply base and develop more cooperative, long-term relationships with key suppliers, a practice that has fostered more opportunities to work together on environmental issues. This study aims to analyze the relationship Life Cycle Assessment (LCA), Environment Supply Chain and Sustainability Supply Chain. 


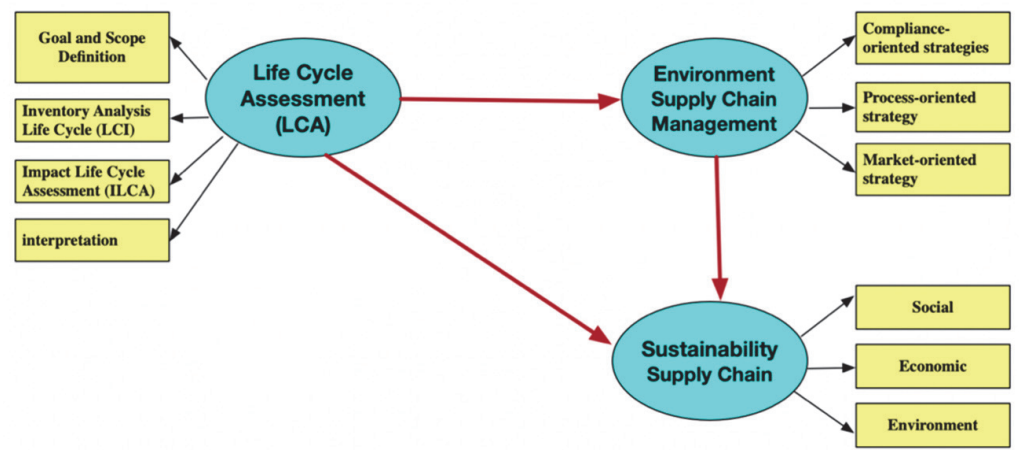

Fig. 2. Research Framework

\section{The hypotheses in this study are:}

H1: Does LCA affect the Supply Chain Management Environment in Manufacture, Indonesia?

H2: Does the SCM Environment affect the Supply Chain sustainability in Manufacture, Indonesia?

H3: Does LCA affect the Supply Chain Sustainability in Manufacture, Indonesia?

H4: Does LCA affect the Supply Chain Sustainability through Environment SCM in Manufacture, Indonesia?

\section{Research methods and results}

This research is exploratory in nature with survey techniques as a means of collecting data. The research variable in this study is the Life Cycle Assessment (LCA). LCA indicators (ISO 14040 Series (14040 to 14049) are objective definition and scope determination; inventory analysis; impact assessment and Environmental Supply Chain Management variable plays as mediation. Environmental Supply Chain Management Indicator is a compliance-oriented strategy: Comply with rules and regulations with the help of tip techniques pipeline; Process-oriented strategy: Strives to control the environmental load caused by the production process through integrated production steps that achieve compliance with government regulations and regulations and better returns (prevention of paying for pollution). Market-oriented strategy: Aims to reduce the burden environment caused by product design to achieve competitive advantage. The object of research is selected manufacture in Indonesia. The population in this study is Employees selected manufacture in Indonesia with a sample of 100 people. The analysis method is carried out on data obtained from the results of the questionnaire answers and are used to analyze data in the form of numbers and calculations with statistical methods. The data must be classified in certain categories by using certain tables to make it easier to analyze, for that the Smart PLS analysis program will be used. Convergent validity calculation aims to determine instrument items that can be used as indicators of all latent variables. The convergent validity test results are measured based on the value of the loading factor (outer loading) of the latent indicator (construct). The results of the convergent validity test which have an outer loading value below 0.70 will be dropped from the model, then the results of the initial analysis of the outer loading value can be seen as visualized in Table 1 as follows:

Table 1

Convergent Validity Test Results

\begin{tabular}{|c|c|c|c|c|}
\hline Variable & Indicator & Outer Loading & Requirement & Note \\
\hline \multirow{8}{*}{$\begin{array}{c}\text { Life Cycle Assessment } \\
\text { (X) }\end{array}$} & $\mathrm{X} 1$ & 0.790 & $>0,7$ & Valid \\
\hline & $\mathrm{X} 3$ & 0.722 & $>0,7$ & Valid \\
\hline & $\mathrm{X} 4$ & 0.793 & $>0,7$ & Valid \\
\hline & X5 & 0.768 & $>0,7$ & Valid \\
\hline & X6 & 0.793 & $>0,7$ & Valid \\
\hline & $\mathrm{X} 7$ & 0.753 & $>0,7$ & Valid \\
\hline & $\mathrm{X} 8$ & 0.724 & $>0,7$ & Valid \\
\hline & X9 & 0.743 & $>0,7$ & Valid \\
\hline \multirow{5}{*}{$\begin{array}{c}\text { Environment Supply } \\
\text { Chain Management } \\
\text { (Z) }\end{array}$} & Z1 & 0.781 & $>0,7$ & Valid \\
\hline & $\mathrm{Z} 2$ & 0.815 & $>0,7$ & Valid \\
\hline & $\mathrm{Z3}$ & 0.877 & $>0,7$ & Valid \\
\hline & $\mathrm{Z4}$ & 0.870 & $>0,7$ & Valid \\
\hline & $\mathrm{Z5}$ & 0.841 & $>0,7$ & Valid \\
\hline \multirow{7}{*}{$\begin{array}{l}\text { Sustainabilty Supply } \\
\text { Chain } \\
\text { (Y) }\end{array}$} & Y1 & 0.795 & $>0,7$ & Valid \\
\hline & Y2 & 0.704 & $>0,7$ & Valid \\
\hline & Y3 & 0.827 & $>0,7$ & Valid \\
\hline & Y4 & 0.797 & $>0,7$ & Valid \\
\hline & Y5 & 0.853 & $>0,7$ & Valid \\
\hline & Y6 & 0.791 & $>0,7$ & Valid \\
\hline & Y7 & 0.807 & $>0,7$ & Valid \\
\hline
\end{tabular}


Discriminant validity is a reflexive indicator measurement based on cross loading with its latent variables. Another method is to compare the square root of average variance extracted (AVE) value for each construct, with the correlation between other constructs in the model. In this connection, it is recommended that the measurement value should be greater than 0.50. Furthermore, the results of the Discriminant validity test can be seen as shown in Table 2 as follows:

Table 2

$\underline{\text { Results of Discriminant Validity Testing }}$

\begin{tabular}{ll}
\hline Variable & Average variance extracted (AVE) \\
\hline Life Cycle Assessment (X) & 0.580 \\
Environment Supply Chain Management (Z) & 0.701 \\
Sustainability Supply Chain (Y) & 0.636 \\
\hline
\end{tabular}

Source: Results of analysis using SmartPLS

Testing composite reliability aims to test the validity of the instrument in a research model. The results of testing for composite reliability can be seen as shown in Table 3 as follows:

Table 3

Composite Reliability Test Results from the Research Model

\begin{tabular}{llll}
\hline Variable & Composite Reliability & Cronbach's Alpha & Note \\
\hline Life Cycle Assessment (X) & 0.921 & 0.986 & Reliable \\
Environment Supply Chain Management (Z) & 0.921 & 0.893 & Reliable \\
Sustainability Supply Chain (Y) & 0.924 & 0.841 & Reliable \\
\hline S
\end{tabular}

Source: Results of analysis using SmartPLS

Table 3 above is a table of the composite reliability values of the research model. The table shows that each variable has a composite reliability value above 0.7 with the lowest value of 0.921 from the Life Cycle Assessment $(\mathrm{X})$ and Environment Supply Chain Management (Z) variables and the highest value of 0.924 from the Sustainability Supply Chain (Y) variable. It can be concluded that the research model has met the value of composite reliability. The table shows that each variable has a Cronbach's alpha value above 0.6 with the lowest value of 0.841 from the Sustainability Supply Chain (Y) variable and the highest value of 0.986 from the Life Cycle Assessment $(\mathrm{X})$ variable. From these results it can be concluded that the research model has met the value of Cronbach's alpha. From the model above, it can be concluded that the model has met the criteria of Composite Reliability and Cronbach's Alpha so that the research model has met the reliability criteria and is a reliable and reliable measuring tool. Before conducting the analysis, first, the empirical research model is tested or evaluated. The results of testing the empirical model of this study can be seen in Fig. 3

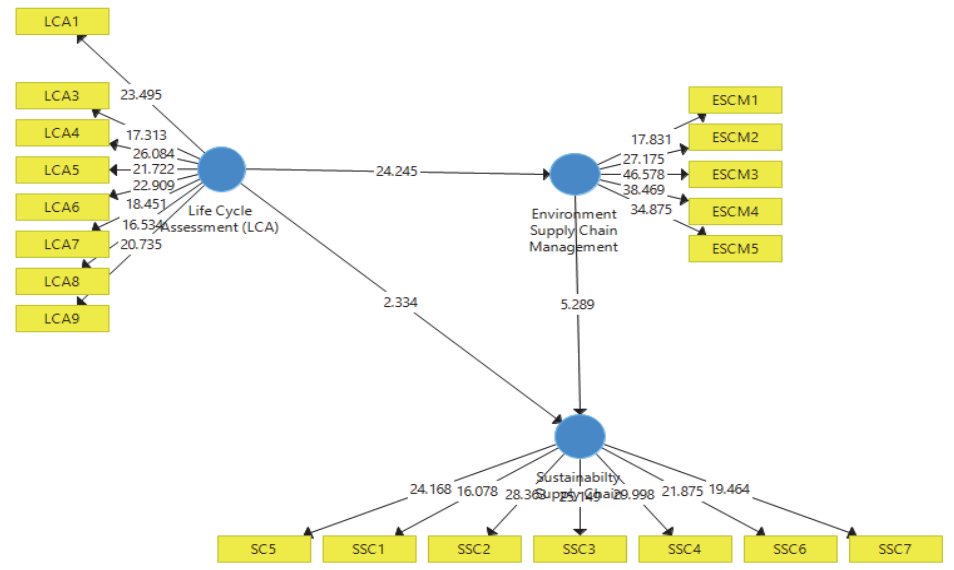

Fig. 3. Results of Analysis with PLS

\section{a. Test of the Coefficient of Determination / $R$ Square $\left(R^{2}\right)$}

Inner model evaluation is done by looking at the coefficient of determination. The coefficient of determination aims to measure how far the model's ability to explain the variance of the dependent variable. The value of the coefficient of determination is between 0 and 1 . The coefficient of determination $\left(R^{2}\right)$ is close to the value of 1 . The value of $R^{2}$ explains how much the independent variable hypothesized in the equation is able to explain the dependent variable.

Table 4

Value of R Square $\left(\mathrm{R}^{2}\right)$ from the Research Model

\begin{tabular}{lll}
\hline Variable & R Square & R Square Adjusted \\
\hline Environment Supply Chain Management & 0.697 & 0.695 \\
Sustainability Supply Chain & 0.736 & 0.732 \\
\hline Source: Results of analysis using SmartPLS & &
\end{tabular}

Source: Results of analysis using SmartPLS 
As can be seen in Table 4, the relationship between constructs based on the Adjusted R-Square value can be explained that the Environment Supply Chain Management is 0.695, which shows that $69.5 \%$ of the Environment Supply Chain (Z) variable can be influenced by the Life Cycle Assessment $(\mathrm{X})$ variable, while the remaining 30.5\% is influenced by other variables outside the study. While the relationship between constructs based on the R-square Adjusted value can be explained that the Sustainability Supply Chain (Y) variable is 0.732 , this indicates that $73.2 \%$ of the Sustainability Supply Chain variable can be influenced by the Life Cycle Assessment (X) variable and the Environment Supply Chain. (Z), while the remaining $26.8 \%$ is influenced by other variables outside the study

\section{b. Overall Structural Model Validation with Goodness of Fit Index (GoF)}

The purpose of conducting the Goodness of Fit Index (GoF) test is to validate the combined performance of the measurement model (outer model) and the structural model (inner model) which is obtained through the following calculations:

$$
\mathrm{GoF}=\sqrt{A V E \times R^{2}}=\sqrt{0.639 \times 0.717}=0.677 \quad \mathrm{AVE}=(0.580+0.701+0.636) / 3=0.639 \quad \text { R square }=(0.697+0.736) / 2=0,717
$$

The result of the calculation of the Goodness of Fit Index (GoF) shows a value of 0.677. According to Hair et al. (2006), the GoF value is small $=0.1$, medium $\mathrm{GoF}=0.25$ and large $\mathrm{GoF}=0.36$. Based on these results, it can be concluded that the combined performance of the measurement model (outer model) and the structural model (inner model) as a whole is good because the Goodness of Fit Index (GoF) value is more than 0.36 (large scale GoF).

\section{c. Predictive Relevance Test (Q2)}

The purpose of conducting predictive relevance (Q2) testing is to validate the model. The results of the calculation of Q2 are as $\mathrm{Q} 2=1-\left(1-\mathrm{R}^{2}\right)\left(1-\mathrm{R} 2^{2}\right)==1-(1-0.697)(1-0.736)=0.9201$. Based on the results of the predictive relevance (Q2) above, it shows a value of 0.9201 . In this research model, endogenous latent variables have a predictive relevance (Q2) value greater than 0 (zero) so that the exogenous latent variables as explanatory variables are able to predict the endogenous variables, namely the Sustainability Supply Chain, or in other words prove that this model is considered to have a good predictive relevance (i.e. $\mathrm{DF}=\mathrm{n}-\mathrm{k}=153-3=150$ ). In the statistical table, the $t$ table value with a value of 150 is 1.655 with a significance level $(\alpha)$ of 0.05 . The way of making decisions is:

- If P-Values $>0.05$ or $\mathrm{t}$ count $<\mathrm{t}$ table, Ho is accepted and Ha is rejected.

- If $\mathrm{P}$-Values $<0.05$ or $\mathrm{t}$ count $>\mathrm{t}$ table, Ho is rejected and Ha is accepted.

The results of hypothesis testing using SmartPLS software can be seen in Table 5 below:

Table 5

Path Coefficient Values, t-Statistics, and P-Values

\begin{tabular}{|c|c|c|c|c|}
\hline Relations Between Constructs & $\begin{array}{c}\text { Original } \\
\text { Sample }(\mathrm{O})\end{array}$ & $\begin{array}{c}\text { T Statistics } \\
(|\mathrm{O} / \mathrm{STDEV}|)\end{array}$ & P Values & Note \\
\hline \multicolumn{5}{|l|}{ Direct Influence } \\
\hline Life Cycle Assessment $(\mathrm{X}) \rightarrow$ Environment Supply Chain Management $(\mathrm{Z})$ & 0.839 & 24.25 & 0.000 & $\begin{array}{l}\text { Positive } \\
\text { Significant }\end{array}$ \\
\hline Environment Supply Chain Management (Z) $\rightarrow$ Sustainabilty Supply Chain (Y) & 0.617 & 18.57 & 0.000 & $\begin{array}{l}\text { Positive } \\
\text { Significant }\end{array}$ \\
\hline Life Cycle Assessment $(\mathrm{X}) \rightarrow$ Sustainabilty Supply Chain (Y) & 0.782 & 5.29 & 0.000 & $\begin{array}{l}\text { Positive } \\
\text { Significant }\end{array}$ \\
\hline \multicolumn{5}{|l|}{ Indirect Influence } \\
\hline $\begin{array}{l}\text { Life Cycle Assessment }(\mathrm{X}) \rightarrow \text { Environment Supply Chain Management }(\mathrm{Z}) \text {-> } \\
\text { Sustainabilty Supply Chain (Y) }\end{array}$ & 0.512 & 5.021 & 0.000 & $\begin{array}{l}\text { Positive } \\
\text { Significant }\end{array}$ \\
\hline
\end{tabular}

1. The effect of the influence of Life Cycle Assessment $(\mathrm{X})$ is positive and significant on the Environment Supply Chain Management (Z)

Based on Table 5, it is known that the statistical value is 24.25 which is greater than the value of t table $=1.655$, and the value of P-Values $=0.000$ which is smaller than $\alpha=0.05$. The coefficient value is positive, which is 0.839 , which means that the Life Cycle Assessment (X) variable has a positive effect on the Environment Supply Chain Management (Z) variable. Thus, the H1 hypothesis in this study which states that "Life Cycle Assessment (X1 has a positive and significant effect on Environmental Supply Chain Management (Z)" is accepted.

2.Effect of Environment Supply Chain Management (Z) positively and significantly on Sustainability Supply Chain (Y)

Based on Table 5, it is known that the statistical value is 18.57 which is greater than the value of $t$ table $=1.655$, and the value of P-Values $=0.000$ which is smaller than $\alpha=0.00$. The coefficient value is positive, namely 0.617 , which means that the Environment Supply Chain Management (Z) variable has a positive effect on the Sustainability Supply Chain (Y) variable by $61.7 \%$. Thus, the hypothesis H3 in this study which states that "Environmental Supply Chain Management (Z) has a positive and significant effect on the Sustainability Supply Chain (Y)" is accepted.

3.There is a positive and significant effect of Life Cycle Assessment (X) on Sustainability Supply Chain (Y)

Based on Table 5, it is known that the value of $\mathrm{t}$ statistics is 5.29 which is greater than the value of $\mathrm{t}$ table $=1.655$, and the 
value of $\mathrm{P}$-Values $=0.000$ which is smaller than $\alpha=0.05$. The coefficient value is positive, which is 0.782 , which means that the Life Cycle Assessment (X) variable has a positive effect on the Sustainability Supply Chain (Y) variable by $78.2 \%$. Thus, the $\mathrm{H} 2$ hypothesis in this study which states that "Life Cycle Assessment (X) has a positive and significant effect on Sustainability Supply Chain (Y)" is accepted.

4. There is a positive and significant effect of Life Cycle Assessment (X) on the Sustainability Supply Chain (Y) through the Environment Supply Chain Management (Z)

Based on Table 5, it is known that the value of t statistics for the Life Cycle Assessment (X) variable is 5.021 which is greater than the value of $t$ table $=1.655$, and the value of P-Values $=0.000$ which is smaller than $\alpha=0.05$. The coefficient value is positive, which is 0.512 , which means that the Life Cycle Assessment (X) variable has a positive effect on the Sustainability Supply Chain (Y) variable through the Environment Supply Chain Management (Z) of 51.2\%. Thus, the hypothesis $\mathrm{H} 4$ in this study which states that "Life Cycle Assessment (X) is positive and significant towards the Sustainability Supply Chain (Y) through the Environment Supply Chain Management (Z)" is accepted.

\section{Discussion}

\section{Life Cycle Assessment affects the Environment Supply Chain Management}

This research proves that the Life Cycle Assessment has an effect on the Environment Supply Chain Management. This means that the greater the influence of Life Cycle Assessment, the better Environment Supply Chain Management. The results of this study are in line with the research of Sari et al. (2012) which states the importance of Life Cycle Assessment for sustainability. Based on observations, it was found that the company has made a flow model of the inventory cycle starting from raw materials, processing, assembling, final products to waste analysis. Meanwhile, what needs to be improved is related to improvements in input and output data, for example data on raw materials, various types of energy, emissions to air, land or water with substances. With an increase in the calculation of quantify the environmental inputs and outputs.

\section{Environment Supply Chain Management has an effect on Sustainability Supply Chain}

This study explains that there is an influence related to Environment Supply Chain Management on Sustainability Supply Chain. The results of this study support Sutawijaya and Nawangsari's (2019) research which states that Green Supply Chain management has an effect on sustainability. The research object found that the company has integrated steps related to production / service to achieve compliance with government regulations and laws. Based on observations, what needs to be improved is the development of knowledge about supply chain products, product design and supply chain technology. With the increasing knowledge of Environment Supply Chain Management, it is expected that the company will increase the competitive advantage.

\section{Life Cycle Assessment affects the Sustainability Supply Chain}

This study proves that the Life Cycle Assessment has an effect on the Sustainability Supply Chain, meaning that the better the Life Cycle Assessment, the better Sustainability Supply Chain. This is in line with Arieyanti's research (2019) which states the importance of Life Cycle Assessment for sustainability. Sustainability Supply Chain in the research object has gone quite well proven by the presence of organizational attention related to the product cycle in the company. Based on observations, things that need to be improved regarding the Sustainability Supply Chain are so that companies can comply with health and safety and carry out education and training.

\section{Life Cycle Assessment affects the Sustainability Supply Chain through the Environment Supply Chain Management}

The results of this study state that the Life Cycle Assessment affects the Sustainability Supply Chain through the Environment Supply Chain Management, which means that the effect of the Life Cycle Assessment will be greater if it is supported by the Sustainability Supply Chain. This supports the research results conducted by Hagelaar and Van der Vorst (2001) which states that the implementation of the Life Cycle Assessment has an influence on Supply Chain Management for company sustainability

\section{Conclusions}

In this study, the authors can prove several views that the Life Cycle Assessment (LCA) affects the Environmental Supply Chain Management. Then Environmental Supply Chain Management affects the Sustainability Supply Chain. Continued Life Cycle Assessment (LCA) affects Supply Chain Sustainability. Finally, Life Cycle Assessment (LCA) affects Supply Chain Sustainability through Environmental Supply Chain Management. The suggestions that the authors can convey in this article are as follows:

For the Life Cycle Assessment (LCA) variable, it is recommended that companies make improvements to measure environmental inputs and outputs. Regarding input and output data in the production process, for example for raw material data; different types of energy; various emissions to the air, land or water to protect the environment. Furthermore, the Supply Chain Management Environment variable; the authors advise to develop knowledge through training and 
development for employees about supply chain management, product design, and supply chain technology. In addition to the Sustainability Supply Chain variable, it is recommended that companies develop occupational health and safety programs and optimize their application in the company. Finally, for further research, you can add independent variables that affect the Sustainability Supply Chain. Besides that, it can also develop a research model from the results of this study

\section{References}

Alfalla-Luque, R., Medina-Lopez, C., \& Dey, P. K. (2013). Supply chain integration framework using literature review. Production Planning \& Control, 24(8-9), 800-817.

Arieyanti, D. A. (2019). Potential analysis of environmental impact of sugarcane plantation using life cycle assessment (lca) approach, Jurnal Litbang, 15(1), 51-64.

Aziz, R., Chevakidagarn, P., Danteravanich, S. (2016). Environmental impact evaluation of community composting by using life cycle assessment: a case study based on types of compost product operations. Walailak Journal of Science and Technology (WJST), 13(3), 221-233.

Carter, C. R., \& Rogers, D. S. (2008). A framework of sustainable supply chain management: moving toward new theory. International Journal of Physical Distribution \& Logistics Management, 38(5), 360-387.

Chauhan, M. K., Chaudhary, S., \& Kumar, S. (2011). Life cycle assessment of sugar industry: A review. Renewable and Sustainable Energy Reviews, 15(7), 3445-3453.

Combined Use of Analytical Tools. Dordrecht: Kluwer.

Crum, M., Poist, R., Carter, C. R., \& Easton, P. L. (2011). Sustainable supply chain management: evolution and future directions. International Journal of Physical Distribution \& Logistics Management, 37(8), 631-669.

Farahani, R. Z., Asgari, N., \& Davarzani, H. (Eds.). (2009). Supply chain and logistics in national, international and governmental environment: concepts and models. Springer Science \& Business Media.

Finkbeiner, M. (2013). The future of LCA in the ISO 14000 Family. International Journal of Life Cycle Assessment, 18 (1), $1-4$.

Hagelaar, G. J., \& Van der Vorst, J. G. (2001). Environmental supply chain management: using life cycle assessment to structure supply chains. The International Food and Agribusiness Management Review, 4(4), 399-412.

Hair Jr, J. F. (2006). Black, WC/Babin, BJ/Anderson, RE \& Tatham, RL (2006): Multivariate Data Analysis. Auflage, Upper Saddle River.

Heizer, J. (2016). Operations management, 11/e. Pearson Education India.

Liang, S., \& Chang, W. L. (2008). An empirical study on relationship between green supply chain management and SME performance in China. In International conference on management science and engineering (pp. 611-618).

Mentzer, J. T., DeWitt, W., Keebler, J. S., Min, S., Nix, N. W., Smith, C. D., \& Zacharia, Z. G. (2001). Defining supply chain management. Journal of Business Logistics, 22(2), 1-25.

Nawangsari, L. C., \& Sutawijaya, A. H. (2019). A framework of green contruction supply chain. Internmational Journal of Supply Chain Management, 8(1), 162.

Sari, D. P., Hartini, S., Rinawati, D. I., \& Wicaksono, T. S. (2012). Measurement of Eco-efficiency Levels Using Life Cycle Assessment to Create Sustainable Production in Batik Small and Medium Industries. Journal of Industrial Engineering, 14, 137-144.

Sutawidjaya, A. H., \& Nawangsari, L. C. (2017). A Framework Model on Supply Chain Event Organization (Cases in Event Organizer, Jakarta). Review of Integrative Business and Economics Research, 6, 277.

Van Hoek, R. I. (1999). From reversed logistics to green supply chains. Supply Chain Management: An International Journal, 4(3), 129 - 135.

Wagner, M., Schaltegger, S., \& Wehrmeyer, W. (2001). The relationship between the environmental and economic performance of firms. Greener Management International, 34(1), 94-111.

Statistik Lingkungan Hidup Indonesia. (2018). https://www.bps.go.id/publication/statistik-lingkungan-hidup-indonesia2018.html

Tools for Environmental Design and Management in a Systems Perspective: The

Wrisberg, M.N., Udo de Haes, H.A., Triebswetter, U., Eder, P., and Clift, R. (2002). Principles of Life Cycle Assessment, Relationships between various tools to assess the sustainability of a good or service

Internet:

http://ghdx.healthdata.org/organizations/central-bureau-statistics-indonesia

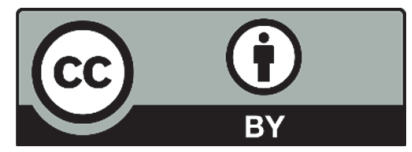

(C) 2021 by the authors; licensee Growing Science, Canada. This is an open access article distributed under the terms and conditions of the Creative Commons Attribution (CC-BY) license (http://creativecommons.org/licenses/by/4.0/). 